\title{
ISLAMISASI DI CIREBON: PERAN DAN PENGARUH WALANGSUNGSANG PERSPEKTIF NASKAH CARIOS WALANGSUNGSANG
}

\author{
Siti Zulfah \\ UIN Sunan Kalijaga (zulfah.azra.91@gmail.com)
}

\begin{abstract}
Islamization is a theme that continues to this day. Islamization can be defined as Islamic, through the conversion process of Religion. Cirebon Islamic Society is the result of mixing between indigenous (ethnic Javanese-Sunda) with immigrants (traders-Sufis) who are Muslims. Walangsungsang plays an active role in the opening, the spread of civilization (culture), the founder of the center of Islamic government. Keraton Pakungwati as the legitimacy of central Islamic government in Cirebon. This paper seeks to identify a biography of Walangsungsang (fact or myth) and to understand how Walangsungsang's role and influence in the Islamization of Cirebon is the perspective of the Carios Walangsungsang manuscript. This research is done by searching the manuscript of Cariyos Walangsungsang, references both books and research results about the history of Islam in Cirebon, and placing some historical places in Cirebon such as Keraton, petilasan (Tomb of Mbah Kuwu Cirebon Girang) Walangsungsang. Historical Approach to tracing historical facts, then explored in chronological order. This paper produces historical facts that the role of Walangsungsang as the first spreader of Islam in Cirebon from the HinduBuddhist kingdom (Padjajaran), cultivate Cirebon land, and founder of Pakungwati Islamic Kingdom. For his role Walangsungsang influential and changing Religion and culture of Islamic society Cirebon become more characteristic with the pattern of arranging a diverse society and a complex social hierarchy.
\end{abstract}

Keywords: islamization, Walangsungsang, Cirebon.

\begin{abstract}
Abstrak
Islamisasi merupakan tema yang sampai saat ini terus berlangsung. Islamisasi dapat didefinisikan sebagai pengislaman, melalui proses konversi Agama. Masyarakat Islam Cirebon merupakan hasil percampuran antara pribumi (etnis Jawa-Sunda) dengan pendatang (para pedagang-sufi) yang beragama Islam. Walangsungsang berperan aktif dalam pembuka, penyebar peradaban (budaya), pendiri pusat pemerintahan Islam. Keraton Pakungwati sebagai legitimasi pusat pemerintahan Islam di Cirebon. Tulisan ini berusaha mengidentifikasi biografi Walangsungsang (fakta atau mitos) dan memahami bagaimana peran dan pengaruh Walangsungsang dalam Islamisasi Cirebon persepektif naskah Carios Walangsungsang. Penelitian ini dilakukan dengan melalui penelusuran naskah Cariyos Walangsungsang, refrensi baik buku maupun hasil penelitian tentang sejarah Islam di Cirebon, serta menjajakkan beberapa tempat bersejarah di Cirebon seperti Keraton, petilasan (Makam Mbah Kuwu Cirebon Girang) Walangsungsang. Pendekatan Historis guna penelusuran fakta sejarah, kemudian dieksplanasi yang dikemas secara kronologis. Tulisan ini menghasilkan fakta sejarah bahwa peran Walangsungsang sebagai penyebar Islam pertama di Cirebon dari kalangan Kerajaan Hindu-Budha (Padjajaran), membabad tanah Cirebon, dan pendiri Kerajaan Islam Pakungwati. Atas perananya Walangsungsang berpengaruh dan perubahan Agama dan budaya masyarakat Islam Cirebon menjadi lebih berkarakteristik dengan pola penyusunan masyarakat yang beragam serta hierarki sosial yang kompleks.
\end{abstract}


Kata Kunci: Islamisasi, Walangsungsang, Cirebon.

\section{A. Pendahuluan}

Cirebon dikenal sebagai kota Wali $^{1}$ dan kota pelabuhan ${ }^{2}$ menyimpan sejarah panjang di masa lalu, khususnya mengenai peristiwa cikal bakal penyebaran Islam di Jawa Barat. Hal itu tidak bisa dilepaskan dari peran pedagang muslim, ulama, dan tokoh pribumi, seperti Walangsungsang. Mereka berjuang dalam mewujudkan sebuah nagari bercorak Islam dan bebas dari kekuasaan pemerintah kerajaan Sunda-Galuh. Setelah nagari Cirebon terbentuk, kota ini menjadi sering

1 Dalam naskah Purwaka Caruban Nagari disebutkan bahwa oleh para wali songo, Cirebon (Caruban) disebut puser bumi, dikarenakan Nagari Caruban (Cirebon) berada di tengah-tengah pulau Jawa, dalam pengertian lain sebagai pusat penyebaran Islam bagi Jawa Barat atau tanah Sunda, Lihat. Atja, Carita Purwaka Caruban Nagari (Bandung: Proyek Pengembangan Permuseuman, 1986), hlm. 29.

2 Mengapa Cirebon dapat dikatakan sebagai kota pelabuhan, itu dikarenakan Cirebon yang letak geografis berada di wilayah Pantai Utara Jawa. Menurut Thomas Stamford Raffles, dalam karyanya yang berjudul The History of Java, dikatakan bahwa sepanjang Pantai Utara ada beberapa tempat yang dapat dijadikan pelabuhan, dengan syarat lautnya dapat disinggahi sepanjang tahun untuk berlabuh kapal-kapal yang melakukan perdagangan, kota pelabuhan Cirebon salah satunya. Lihat. Thomas Stamford Raffles, The History of Java (Yogyakarta: Narasi, 2008), hlm. 6. disinggahi pedangang asing melalui jalur perlintasan perdagangan yang bertaraf Internasional. Keberhasilan penyebaran Islam di Cirebon tidak lepas dari kiprah Walangsungsang, pendirian Istana Pakungwati kemudian berkembang menjadi Kesultanan Cirebon yang merupakan simbol kejayaan Islam pada abad ke15 dan 16 M. Peran ulama sebagai penyebar Islam menjadi titik awal Islamisasi di Cirebon.

Gelar Walangsungsang yang disandangnya selama kiprahnya dalam menyebarkan Islam seperti Cakrabuana, Sri Mangana. Oleh karena itu, penulis ingin semakin jauh mengetahui secara genetik dan akar historis mengenai Walangsungsang dalam Islamisasi di Cirebon. Penulis melihat kondisi masyarakat Cirebon terhadap "penghormatan" situs petilasan Walangsungsang atau "Embah Kuwu Cirebon Girang" yang dianggap sebagai "wali" (orang suci) berpengaruh dalam kehidupan sosial keagamaan masyarakat Cirebon. Secara geografis letak situs tersebut berada di desa Cirebon Girang, kecamatan Cirebon selatan, kabupaten DT II Cirebon blok 
Keramat Talun $\pm 7 \mathrm{Km}$ dari jantung Kota Cirebon. ${ }^{3}$

\section{Peranan Walangsungsang} sangat berpengaruh terhadap sebagian masyarakat Cirebon, hal demikian tidak lepas dari peran aktifnya dalam menyebarkan Islam. Selain itu, cara masyarakat dalam menunjukkan penghormatan terhadap tokoh yang berpengaruh ini (Walangsungsang) ada keterikatan untuk mengunjungi makam tokoh pujaannya tersebut. Menurut asumsi masyarakat Cirebon bahwa dengan keyakinan dan keharuman tokoh atas jasanya, Walangsungsang masih dihormati, bahkan setelah wafat, sehingga mereka menganggap tempat itu mengandung berkah.

Dari beberapa fakta sejarah yang telah disebutkan di atas studi tentang sejarah perkembangan Islam di Cirebon menurut manuskrip Carios Walangsungsang ${ }^{4}$ atas dasar latar belakang keluarga Walangsungsang yang berasal dari

\footnotetext{
3 Muhammad Amin, Pangeran Walangsungsang (Embah Kuwu Sangkan Cirebon Girang) Penyebar Agama Islam di Tanah Cirebon, (Cirebon: tanpa penerbit, 2008), 20. Keterangan: Muhammad Amin merupakan Mantan Kepala Desa Cirebon Girang, pada saat itu Juru Kunci Keramat Talun ialah Sujai Abdullah.
}

${ }^{4}$ Carios Walangsungsang manuskrip yang telah disunting oleh Raffan S. Hasyim dkk, Cariyos Walangsungang (Jawa Barat; DISBUDPAR Jawa Barat). kerajaan bercorak Hindu-Sunda. Walangsungsang lebih memilih menyebarkan agama Islam daripada menjadi pewaris tahta di kerajaan Padjajaran. Karena itu, peran Walangsungsang dalam perkembangan Islam di Cirebon menjadi hal yang menarik untuk ditulis perjalanan sejarahnya. Walangsungsang tidak hanya membuka lahan atau wilayah Cirebon (dulu Caruban) melainkan membangun peradaban Islam yang berkembang pesat hingga abad ke-16 Masehi, yakni pada masa Syarif Hidayatullah (Sunan Gunung Jati). Selain itu, Walangsungsang menjadikan pelabuhan yang semula berfungsi sebagai jalur hubungan antara pejabat daerah (Caruban) dengan kerajaan Galuh. Walangsungsang menjadikan pelabuhan semakin ramai dari berbagai Negara (Arab, Gujarat, China, Persia) yang singgah di pelabuhan tersebut, mereka tidak sekedar untuk memenuhi bahan pokok selama berdagang tetapi membawa pengaruh baru (agama Islam) yang dibawa oleh mereka. Sejarah Walangsungsang masih perlu dikaji kembali dikarenakan interpretasi intelektual terkait data sejarah antara fakta atau tokoh legenda (mitos). Dalam penelitian ini tidak sekedar berusaha mencari "fakta sejarah" dibalik realita 
sekarang tetapi kedalaman interpretasi sebuah fakta. Alasan lain penulis dalam melakukan penelitian ini karena sangat jarang sejarawan yang mengkaji secara mendalam mengenai studi tentang Islam pada masa klasik di wilayah Indonesia, khususnya Cirebon, yaitu abad ke-15 $M$ dengan alasan terkait sumber. Karena itu, penelitian ini dilakukan guna menemukan jawaban atas permasalahan penulis sebagaimana yang tertulis di atas. Oleh karena itu berikut beberapa rumusan masalah: 1. Mengapa tokoh lokal (Walangsungsang) lebih dianggap sebagai tokoh mitos daripada pendatang yang masih memiliki garis keturunan pribumi?.,2. Bagaimana perkembangan Islam di Cirebon yang diperankan oleh tokoh yang dianggap mitos (keberadaan tokoh)?

Penelitian ini termasuk dalam kategori penelitian kepustakaan (library research), ${ }^{5}$ yakni suatu penelitian yang menggunakan bukubuku atau sejenisnya sebagai sumber data. ${ }^{6}$ Metode yangdigunakan dalam penelitianini sudah menjadi keharusan bagi para sejarawan dalam menggunakan metode sejarah untuk

5 Winarno Surakhmad, Penelitian Ilmiah, (Bandung: Tarsito, 1994), hlm. 251-263.

6 Sutrisno Hadi, Metodologi Research, (Yogyakarta: Andi Offiset, 1990), hlm. 9.

melihat kejadian-kejadian di masa lampau dan menganalisa secara kritis terhadap data yang diperoleh sehingga pada akhirnya menghasilkan sintesa. ${ }^{7}$

Metode sejarah memusatkan perhatian data di masa lalu berupa pengalaman, dokumen, arsip, bendabenda bersejarah, dan tempat-tempat yang dianggap keramat (sakral), hal demikian dilakukan untuk memahami berbagai aspek kehidupan masa lalu seperti adat istiadat, kebudayaan, hukum yang berlaku, struktur masyarakat dan pemerintah, kehidupan sosial dan ekonomi, agama, dan lainlain. ${ }^{8}$ Metode sejarah yang terdiri dari empat tahapan, yaitu: Heuristik atau pengumpulan data, verifikasi atau kritik sejarah, keabsahan sumber, interpretasi atau analisisa dan sintesa, historiografi atau penelitian. ${ }^{9}$

Mengenai

pendekatan (approach)merupakan metodologi dalam ilmu sejarah, bahwa penggambaran mengenai suatu

${ }^{7}$ Louis Gottschalk, Mengerti Sejarah, Terj. Nugroho Notosusanto, (Jakarta: UI Pres, 1985), hlm. 32. Lihat. Helius Sjamsuddin, MetodologiSejarah, (Yogyakarta: Ombak, 2007), hlm. 156.

8 Hadiri Nawawi, Metode Penelitian Bidang Sosial, (Yogyakarta: Gajah Mada University Prees, 1993), hlm. 79.

9 Kuntowijoyo, Pengantar Ilmu Sejarah, (Yogyakarta: Bentang, 1995), hlm. 89. 
peristiwa sangat tergantung pada pendekatan, ialah dari sudut pandang mana penulis akan memandang, dimensi mana yang harus diperhatikan, unsur-unsur mana yang diungkapkan. Dalam penelitian ini penulis menggunakan pendekatan sejarah (Historis) sebagai sebuah pendekatan. Pendekatan sejarah yang merupakan pandangan yang mampu mengungkapkan fakta bahwa situasi masa kini adalah produk perkembangan masa lampau. Dalam pendekatan sejarah ini penulismelihat dimensi waktu (kronologis), periodisasi (pembabakan waktu) yang merupakan salah satu proses strukturasi waktu dengan pembagian zaman atau periode. ${ }^{10}$ Dengan perspektif sejarah memandang sebuah peta, kita perlu "merasakan"perbedaan usia bagianbagiannya serta peta perkembangannya dalam waktu dengan mencerminkan dimensi waktu.

Kemudian

menginterpretasikan secara kronologis sehingga menghasilkan fakta sejarah berdasarkan data yang dianalisa.

\section{Pengumpulan sumber (heuristik) dilakukan dengan mengklasifikasi sumber primer dan}

${ }^{10}$ Sartono Kartodirjo, Pendekatan Ilmu Sosial dalam Metodologi Sejarah, hlm. 36-37. sekunder, memisahkan antara sumber tertulis, lisan dan artefack lainya. ${ }^{11}$ Terkait penelitian ini objek penelitian mengenai peran dan pengaruh Walangsungsang dalam Islamisasi Cirebon, 1445-1500 M, bahwa sumber primer yang se-zaman belum ditemukan. Adapun yang ditemukan penulis dalam historiografi tradisional dalam bentuk manuskrip yang ditulis pada abad 19 M. Manuskrip yang ditulis pada tahun 1901 M karya Rohadi Wijaya Jayakelana, Cariyos Walangsungsang, penulis dapatkan dari koleksi Rafan Safari Hasyim, mulanya disalin oleh Pangeran Rahadiwijaya Jayakelana (selaku buyut dari Rafan) bin Pangeran Abdul Hamid Sukmajaya (cangga) yang kemudian diwariskan kepada Pangeran Syarif Rochani Kusumawijaya (kakek), diwariskan R. Syarif Zaenal Asyikintirtawijaya (paman dari Rafan), diwariskan kepada R. Achmad Opan Safari Hasyim (Rafan Hasyim). Naskah tersebut dikatagorikan sebagai sastra sejarah yang memuat informasi kesejarahan. Informasi mengenai naskah Cirebon, pada perkembangannya banyak dibawa keluar dari keraton sejak Pangeran Suryanegara yang keluar dari keraton

11 Helius Sjamsuddin, Metodologi sejarah, (Yogyakarta: Ombak, 2007), hlm. 95. 
Kasepuhan pada tahun $1786 \mathrm{M}$, salah satu keturunannya adalah Pangeran Jayanegara awal (Syekh Idrus), berputra Pangeran Jayanegara akhir, berputra Pangeran Syamsudin awal, berputra Pangeran Syamsudin akhir, Pangeran Abdul Hamid Sukmajaya (selaku cangga dari Rafan Hasyim). ${ }^{12}$ Naskah tersebut dikatagorikan sebagai sastra sejarah yang memuat informasi kesejarahan.Penulis juga menggunakan rujukan buku yang telah ditransliterasi oleh peneliti filologi, seperti, Carita Purwaka Caruban Nagari, Babad Cirebon, Sejarah Cirebon. Penulis mendapatkan dari perpustakaan fakultas Ilmu Budaya Universitas Gajah Mada, perpustakaan Umum Kota Cirebon dan beberapa koleksi Rafan S. Hasyim. Adapunsitus yang dikunjungi penulis seperti Situs Keramat Talun Cirebon Girang (petilasan makam Walangsungsang), Keraton Kasepuhan, Kanoman. Sumber lisan (oral history) digunakan penulis dengan melakukan wawancara. Penulis mewawancari beberapa orang yang dianggap mengetahui sejarah Cirebon yang berkaitan dengan Walangsungsang, seperti juru kunci

12 Hasil wawancara dengan pemilik naskah Cariyos Walangsungsang Bapak Rafan Hasyim, pada tanggal 14 Desember 2014, pukul 11.00 WIB. situs makam Keramat Talun, keraton Kasepuhan dan Kanoman. Melalui wawancara tersebut untuk mencari titik temu antara sumber tulisan dan sumber lisan agar menghasilkan sebuah data sejarah yang akurat.

Setelah memperoleh sumber, langkah selanjutnya metode kritik sumber (verifikasi). Data yang telah didapat kemudian dikelompokkan menurut sejenis. Tahapan ini penulis menyeleksi dan mengidentifikasi sumber-sumber yang telah didapatkan apakah sumber asli atau tidak, baik bentuk wujud maupun isi berdasarkan keakuratan, otentisitas agar mendapatkan sumber yang sesuai dengan objek penelitian.Dalam tahapan ini ada dua langkah dalam pengaplikasiannya ialah kritik eksternal dan internal. ${ }^{13}$ Kritik eksternal, cara melakukan verifikasi atau pengujian terhadap aspek-aspek luar dari sumber sejarahialah suatu penelitian atas asal-usul dari sumber, dengan memastikan keaslian sumber. ${ }^{14}$ Sedangkan kritik internal dengan cara menganalisa isi dokumen, mengecek keakuratan beberapa sumber yang telah didapatkan kemudian dibandingkan dengan

\footnotetext{
${ }^{13}$ Kuntowijoyo, Pengantar Ilmu Sejarah, hlm. 98-99.

${ }^{14}$ Helius Sjamsuddin, Metodologi sejarah.hlm. 132-133.
} 
sumber lain, sehingga menghasilkan fakta individual yang menjadi dasar untuk mengkonstruksi fakta sejarah. Secara teknis langkah tersebut dilakukan dengan membaca, mempelajari dan memahami dari beberapa sumber, kemudian membandingkannya.

Sumber-sumber yang telah diverifikasi akan menghasilkan data yang beragam. Setelah itu data yang beragam ditafsirkan (analisissintesis) ${ }^{15}$ sehingga menghasilkan serangkaian fakta-fakta sejarah yang lebih umum (generalisasi konseptual). ${ }^{16}$ Hasil dari serangkaian sejarah tersebut kemudian disusun secara kronologis baik dalam kurun waktu maupun ruang, agar cerita sejarah mudah dipahami. Dalam tahap ini, penulis akan berusaha menjawab pokok masalah diatas, yakni apa peran Walangsungsang dalam Islamisasi Cirebon, dan pengaruhnya terhadap perkembangan Islam, termasuk melingkupi sosial, budaya dan politik masyarakat Cirebon.

15 Analisis-sintesis maksudnya sumber data yang kita peroleh diuraikan sehingga ditemukan fakta.Setelah di temukan berbagai fakta kemudian disatukan fakta-fakta tersebut secara kronologis. Lihat. Kuntowijoyo, Pengantar Ilmu sejarah, hlm. 100-101.

16 Maksud general konseptual itu yang kita peroleh dari hasil pembacaan kita terhadap fakta.Ibid., hlm. 102.
Selanjutnya, tahap penelitian (historiografi) dalam sebuah penelitian secara sistematis. Tahapan ini penulis melaporkan dan menulis hasil penelitian yang sesuai dengan rancangan penelitian. ${ }^{17}$ Penulis menggunakan konsep interpretasi dan eksplanasi sejarah. Data sejarah yang telah diperoleh kemudian dikritik-analisis sehingga menghasilkan sintesis dari hasil penelitian.

\section{B. Biografi Walangsungsang}

Biografi Walangsungsang secara historis, sebagai titik tolak untuk mengetahui faktor genetik dari Walangsungsang dalam Islamisasi di Cirebon. Walangsungsang dilahirkan di tanah Sunda (Pasundan) ${ }^{18}$ yaitu di Galuh (Kawali), Priangan Timur pada tahun 1423 M. ${ }^{19}$ Ia memiliki dua saudara masing-masing bernama Rara Santang (1427 M) dan Sangara (Kian Santang) lahir pada tahun 1429 M. Mereka putra dari hasil pernikahan antara Pemanah Raja Jayadewata (Prabu Siliwangi)

17 Dudung Abdurahman, Metodologi PenelitianSejarah Islam, (Yogyakarta: Ombak,2011), hlm. 116.

${ }^{18}$ Yang dimaksud dari tanah sunda ialah Tanah Sunda merujuk kepada kerajaan yang pernah ada di Tatar Pasundan (wilayah bagian barat pulau Jawa, sekarang provinsi Jawa Barat dan Banten).

${ }^{19}$ Hamam Rochani, Babad Cirebon, hlm. 43. 
dengan Nyi Subang Larang putra Nagari Singapura di Pesisir Pantai Utara Jawa Barat. Dalam tubuh Ayahnya mengalir darah kerajaan Sunda-Galuh yang berbasis Hindu kelak menjadi raja di kerajaan Padjajaran. ${ }^{20}$ Sedangkan Ibunnya ada titisan darah dari Kerajaan Singapura, ${ }^{21}$ yang memeluk Islam dan seorang santri dari Syekh Qurra di pesantren Qurra Krawang. ${ }^{22}$

Dari segi agama, kedua orang tua Walangsungsang memeluk agama yang berbeda. Raden Pemanah Rasa (Prabu Siliwangi) menganut agama Shang Hyang, sedangkan ibunya, Subang Larang, menganut agama Islam. Penulis melihat dari aspek latar belakang keluarga yang identik dengan

${ }^{20}$ Kerajaan Padjajaran merupakan penerus dari Kerajaan Sunda-Galuh yang berdiri sejak tahun 1482 M. Lihat. Ahmad Rochani, Babad Cirebon, hlm. 35.

21 Kerajaan Singapura merupakan daerah kekuasaan dari Kerajaan Galuh. Kerajaan Singapura yang dalam perkembangannya akan lebih maju dari kerajaan Galuh sehingga diberi otonomi daerah untuk mengawasi daerahnya sendiri. Lihat.Unang Soenarjo, Meninjau Sepintas Panggung Sejarah Pemerintahan Kerajaan Cerbon 1479-1809, hlm. 21, juga Ajta, Carita Purwaka Caruban Nagari, hlm. 35.

${ }^{22}$ Pondok Quraa yang didirikan oleh Syeikh Hasanuddin tersebut merupakan lembaga pendidikan Islam (pesantren) pertama di tanah Pasundan. Kemudian setelah itu muncul pondok pesantren di Amparan Jati daerah Gunung Jati (Syeikh Nurul Jati).Lihat.P.S. Sulendraningrat, Carita Purwaka Tjaruban Nagari, (Djakarta: Bhratara, 1972) hlm. 13-14. kerajaan

Walangsungsang

(Hindu-Budha), memperoleh

pendidikan pertama dari ibunya yang sudah memeluk Islam. ${ }^{23}$ sebagai ibu, Subang Larang tentunya berkewajiban untuk mendidik dan bertanggung jawab terhadap keselamatan putra-putranya. Karena itu Subang Larang mendidik putranya dengan akidah agama Islam. Karena Subang Larang meninggal lebih dulu sehingga dia belum menyelesaikan tugas dalam mendidik putranya dengan sempurna. Kemudian Walangsungsang melakukan pengembaraan ke arah Periangan selatan. Disusul oleh adiknya Rara Santang yang ikut bersama Walangsungsang untuk mengembara mencari jati diri sekaligus guru agama Islam. Keluarnya putra kerajaan dari Istana atas dasar mimpi, dikisahkan dibeberapa sumber tradisional seperti Babad Cirebon, Cariyos Walangsungsang, dalam naskah dijelaskan :

Suatu malam, Walangsungsang bermimpi bertemu dengan Syekh Datuk Kahfi (Nur Jati). Setiap malam ia selalu bermimpi bertemu dengan pendeta itu yang berasal dari Mekah. Syekh Datuk Kahfi bertapa di di Gunung Jati untuk mempelajari ilmu rasul dan ilmu Kanjeng Nabi yakni tentang wiridan dan hakikat

23 Ahmad Hamam Rochani, Babad Cirebon, hlm. 43 . 
rasul.Walangsungsang di dalam mimpinya mendengar suara halus dan lembut, "jika kamu ingin lebih, carilah Datuk Kahfi yang bertapa di Gunung Amparan". 24

Dikisahkan, selama perjalanan pengembaraan Walangsungsang dalam mencari guru agama, ia bertemu petapa di tiga tempat, ialah di Gunung Ciangkup, Gunung Kumbing dan Gunung Amparan Jati. Di Gunung Ciangkup Walangsungsang bersama istrinya, Indhang Geulis dan Rara Santang adiknya, menemuin Resi Danuwarsih, ketiganya disarankan untuk berguru di Padepokan Shang Hyang Nanggo untuk menambah bekal ilmu. Setelah ketiganya menemui Resi Ki Danuwarsih, mereka melanjutkan pengembaraannya ke Gunung Ciangkup, disana ketiganya bertemu dengan Shang Hyang Nanggo. Walangsungsang berserta Istri dan adik perempuannya mendapatkan pelajaran dari Shang Hyang berupa ilmu aji kewibawan, dengan senjatanya Golok Cabang, Bareng dan Topong (Baca: Peci) Waring. ${ }^{25}$

24 Rafan S. Hasyim, dkk, Cariyos Walangsungsang, hlm. 65.

25 Golok Cabang merupakan pusaka yang berfungsi sebagai membabad hutan kala itu, Bareng sejenis dengan alat musik bonang, dan Topong (baca: Peci) Waring azimat ini jika dipakai tidak terlihat oleh siapapun. Ketiganya azimat qur'ani Walangsungsan yang sampai sekarang menjadi amalan para penziarah situs
Ketiganya terdapat tulisan yang mengandung makna, yakni makna tulisan di Golok Cabang yakni "jadilah untuk tujuh perkara" manfaatnya yang disebutkan dalam Q.S. al-A'raf: 97. Kemudian Bareng, manfaatnya "jika ingin menjadi orang Islam yang sejati maka mengamalkan zimat yang empat yakni ilmu syari'ah, tarekat, hakikat dan ma'rifat. Selanjutnya makna dari Topong Waring, manfaatnyauntuk mengajak kebaikan dan mencegah kemungkaran. Beberapa zimat ini yang telah dijelaskan oleh guru Walangsungsang yakni Syekh Nur Jati. Demikian hal tersebut merupakan wujud persepsi masyarakat dalam memahami Islam sekaligus bentuk penghormatan atas upaya Walangsungsang dalam menyebarkan Islam dan pembuka daerah Cirebon,kemudian pada perkembangannya dijuluki sebagai kota wali, dikarenakan penyebaran Islam yang massif.

Walangsungsang setelah melakukan perjalanannya mencari guru agama Islam akhirnya bertemu dengan Syekh Nur Jati di Amparan

Makam Keramat Talun Mbah Kuwu Cirebon Girang. Lihat. Ahmad Hamam Rochani, Babad Cirebon (Cirebon: Dina Kebudayaan dan Pariwisata Kota Cirebon, 2008), hlm. 26-55, Muhammad Amin, Kisah Kehidupan Pangeran Walangsungsang (Cirebon: Tp, 2008), hlm. 2434. 
Gunung Jati. ketika itu Walangsungsang berumur 21 tahun yaitu pada tahun $1444 \mathrm{M}$, berikrar memantapkan diri ingin mendalami agama Islam kemudian bersyahadat. Adapun tahapan dalam menerima pelajaran ajaran agama Islam dari Syekh Nur Jati, Walangsungsang dibimbing dalam mengucapkan dua kalimat syahadat, sekaligus beserta makna dan kandungannya. Kemudian Syekh Nur Jati mengajarkan tentang 5 rukun Islam (syahadat, sholat, zakat, puasa dan haji), sholawat, dzikir, al-Qur'an kitab Suci agama Islam, Fikih dan Tasawuf.

\section{Walangsungsang}

oleh masyarakat Cirebon dikenal dengan sebutan Mbah Kuwu Cirebon Girang yaitu, sejak Mbah Kuwu membuka hutan, sebelumnya di hutan itu sudah ada sebuah rumah milik Ki Danusela. kisah menyebutnya"Witana" (berdasarkan dua kata Awit dan Ana baca: sejak ada) yang diartikan sebagai rumah pemula. $^{26}$ Adapun situs makam Mbah Kuwu Cirebon Girang yang menjadi asumsi masyarakat sekitar bahwa, tempat tersebut merupakan tempat tinggal Walangsungsang beserta keluarga, dan sampai

${ }^{26}$ Witana rumah Ki Gedeng Danusela (Ki Gedeng Alang-alang) sekarang dibangun sebuah keraton Kanoman. Ahmad Hamam Rochani, Babad Cirebon, hlm. 72. sekarang situs tersebut menjadi petapa masyarakat yang berniat mendapat barokah dari Mbah Kuwu sebagai perantara menuju Sang Pencipta Allah SWT. ${ }^{27}$

Melihat dari beberapa refrensi dalam naskah Babad Cirebon, Cariyos Walangsungsang, Purwaka Caruban Nagari terdapat kisah yang menarik dari ketiga naskah tersebut, diantaranya menjelaskan pengembaraan Walangsungsang, hal ini merupakan kategori wujud dari fakta sejarah dalam bentuk mentifacts atau fakta mental, berupa kepercayaan dan nilai-nilai masyarakat sesuai tradisi berfikir. ${ }^{28}$ Dalam sumber cariyos walangsungsang, disebutkan bahwa perjalanan walangsungsang dalam pencariannya terhadap agama Islam merupakan hal yang menarik, sumber tersebut antara lain menceritakan bagaimana perjalanan spiritual Walangsungsang yang bertemu dengan para Dewa (paham Hindu) ke-Shang Hyang-an, bertafakur di Gunung, kemudian dari perjalanannya Walangsungsang

\footnotetext{
${ }^{27}$ Hasil wawancara dengan juru bicara Keramat Talun Mbah Kuwu Cirebon Girang Pangeran Walangsungsang, bapak Muhammad Tohir, umur 47 thn, pada tanggal 24 Januari 2014, pukul: 14.00, di Makam Keramat TalunCirebon Girang-Kabupaten Cirebon.

${ }^{28}$ Kuntowijoyo, Pengantar Ilmu Sejarah, hlm. 94.
} 
mendapatkan azimat dari masingmasing guru agamanya. Hingga kini bagi masyarakat Cirebon menyebutnya Azimat Walangsungsang.

Dari kisah pengembaraan Walangsungsang dan dilihat dari konsep Islamisasi yang deskripsikan oleh Azyumardi Azra dalam buku Jaringan Ulama Timur Tengah, bahwa pada abad pemula Islam di Nusantara sekitar Abad 12, 13 M terjalin hubungan keagamaan dan keilmuan. ${ }^{29}$ Seperti halnya Subang Larang yang belajar Islam dengan ulama dari Gujarat bernama Syekh Qurra sedangkan Walangsungsang belajar agama Islam dengan ulama Arab bernama Syekh Nur Jati, hal demikian, berlanjut hingga abad 17 M. Kemudian, pada mula Islam tersebar ke Nusantara sama halnya di Cirebon, tidak lepas dari unsur Tasawuf sebagai pendekatan ulama dengan kaum pribumi. Dengan begitu, emanasi dalam filsafat Islam dan Tasawuf, melalui hubungan kultur yang erat antara pengembara sufi dengan tokoh pribumi untuk mengintensifkan penyebaran Islam. ${ }^{30}$

29 Azyumardi Azra, Jaringan Ulama Timur Tengah, hlm. 12.

30 Agus Sunyoto, Suluk Syekh Abdul Jalil perjalanan Ruhani Syeikh Siti Jenar Tinjauan Sejarah Tradisional di Cirebon, buku satu, (Yogyakarta: Lkis, 2012), hlm. 46.
Peralihan Agama Hindu-Budha kepada Islam (konversi) disebutkan dalam Cariyos Walangsungsang bahwa suatu saat akan ada pergantian Agama dari Budha ke Islam, itu perkataan mulia yang ditentukan dalam Kitab Budha yang harus diikuti olehmu (Walangsungsang) karena itu semua telah ditakdirkan Hyang. ${ }^{31}$ Dalam konteks ini, Walangsungsang sebagai pribumi dan memiliki peran dalam menyebarkan agama Islam di Cirebon kepada masyarakat Jawa, Sunda di bagian Barat pulau Jawa. Oleh karena itu, dengan mengetahui biografi dari Walangsungsang akan terlihat bagaimana peran-peran Walangsungsang dalam Islamisasi di Cirebon pada era pemula Islam di Cirebon.

\section{Peran Walangsungsang dalam Persebaran Islam di Cirebon}

1. Penyebar Agama Islam Pernikahan raja Pamanah Rasa (Prabu Siliwangi) dengan Subang Larang, putri mangkubumi dari kerajaan Singapura, Ki Gedeng Tapa (Ki Jumajan Jati).Dari pernikahan itulah, Lambat laun Islam mulai masuk di kalangan kerajaan Padjajaran, dan seiring berjalnnya

31 Raffan S. Hasyim, dkk. Cariyos Walangsungsang, (Bandung: Dinas Kebudayaan dan Pariwisata Prov. Jawa Barat, TP), hlm. 71 . 
waktu Subang Larang memeluk Islam kemudian diangkat sebagai murid oleh Syekh Qurra.Dari pernikahan tersebut, dikaruniai dua anak, masing-masing anak tersebut bernama; Walangsungsang (1423 M), Rara Santang (1427 M), dan Sengara (Kian Santang, 1429 M). ${ }^{32}$ Ilmu yang telah dipelajari oleh Subang Larang di Pesantren kemudian diterapkan di dalam Istana Padjajaran. Perilaku keagamaan ini kemudian membuat Walangsungsang berkeinginan untuk belajar Islam.

Dari uraian fakta diatas, dapat diambil benang merah bahwa aktor dalam menyebarkan Islam di Cirebon adalah putra dari Kerajaan Padjajaran yang memiliki kekuasaan atas wilayah dibawah kekuasaanya termasuk daerah pesisir Pantai Utara, Cirebon. Seusai belajar agama kepada gurunya Syekh Nur Jati, Walangsungsang melanjutkan perjuangannya, dengan demikian Islam yang dibawa oleh ulama profesional dengan tujuan menyebarkan Islam, kemudian Walangsungsang dinobatkan sebagai Pengraksabhumi di bawah kepemimpinan Ki Danusela sebagai

32 Ahmad Hamam Rochani, Babad Cirebon, hlm. 34. P. S Sulendraningrat, Sejarah Cirebon, (Jakarta: Departemen Pendidikan dan Kebudayaan, 1978), hlm. 15.
Kuwu I Cirebon. ${ }^{33}$ Kala itu Islam telah dipekenalkan kepada jajaran penguasa, sehingga lambat laut Islam mulai dianut oleh masyarakatnya.

Yang menarik di sini, agama yang dianut oleh jajaran kepemimpinan Ki Danusela, bahwa Ki Danusela sendiri masih beragama Hindu dan Ngraksa-nya (pengurus urusan bidang pertanian dan perikanan) sedangkan Walangsungsang telah menganut agama Islam, jadi toleransi agama telah nampak dalam pakuwuan Cirebon. Selain itu, akibat dari terbukanya gerbang peradaban pada sektor perdagangan banyak suku bangsa asing yang menjalin hubungan dan ketika itu mereka bercampur dengan penduduk pribumi, hingga saat ini keberagaman suku dan agama masih terasa kental.

Walangsungsan dalam menyebarkan Islam masih sangat sederhana, dikarenakan pada kala itu sebagai periode pemula peralihan agama dari Hindu-Budha ke Islam atau konversi. Sehingga banyak ditemukan fakta berupa akulturasi budaya, diantaranya nilai-nilai Islam dengan budaya lokal yang basisnya Hindu-Budha. Menurut P.S

${ }^{33}$ Atja, Carita Purwaka Caruban Nagari, hlm. 33, Lihat juga, Ahmad Hamam Rochani,Babad Cirebon, hlm. 75. 
Sulendraningrat dalam naskah Carita Purwaka Caruban Nagari, tradisi slawat $^{34}$ diawali dari kisah kematian Kuwu Ki Danusela atau Ki Gedeng Alang-alang

kemudianWalangsungsang berusaha mengumpulkan masyarakat pedukuhan Tegal Alang-alang untuk membatu proses peguburan secara Islami (memandikan, mengkafani, menyolati dan menguburkan) akan tetapi para tetangga tidak ada yang datang untuk memenuhi panggilannya, karena upacara kematian secara Islam berbeda dengan upacara kematian orang Budha.

Melihat realita demikian, Walangsungsang menyampaikan pengumuman bahwa "barang siapa yang berkenan membantu proses peguburan akan diberi upah". Akhirnya para tetangga mulai berdatangan dan proses peguburan berjalan lancar. Tindakan demikian, merupakan salah satu karakter agama Hindu-Budha kala itu yaitu membantu sesama dengan

34 Budaya memberikan sesuatu berupa uang kepada orang yang telah membantu dalam mengurusi Jenazah. Bagi pandangan penulis Slawat dimaknai sebagai upaya umat Islam untuk senantiasa bersholawat kepada Nabi Muhammad saw, dalam kanteks ini mendo'akan jenazah. mengharapkan upah. ${ }^{35}$ Sampai saat ini budaya slawat masih dijalankan oleh masyarakat Cirebon, hal itu adalah bentuk ucapan terimakasih karena telah membantu mengurusi jenazah. Walaupun dalam Islam, telah menjadi kewajiban sebagai umat Islam untuk membantu mengurusi proses kematian saudaranya (se-muslim).

Pada dasarnya budaya slawat merupakan upaya Walangsungsang dalam mengenalkan ajaran Islamkepada masyarakat yang masih beragama Hindu-Budha, dengan asumsi ketika membantu sesama manusia menjadi suatu kewajiban tanpa mengharapkan imbalan, berkat niat dan usaha yang muliah, lambat laun sebagian masyarakat berkenan bersaksi dan mengucapkan dua kalimat syahadat. Melalui bimbingan Walangsungsang dan kemudian membuka langgar untuk tempat menimba ilmu.

Menurut beberapa sumber lokal, dalam Naskah Purwaka Caruban Nagarai, Sejarah Cirebon, Cariyos Walangsungsang, bahwa Walangsungsang mendirikan tajug yang dikenal Sang Tajug

35 Muhammad Amin, Kisah Kehidupan Pangeran Walangsungsang(Cirebon: Tp, 2008), hlm. 14-15. 
Jalagrahan $^{36}$ (Jala berarti air; graha berarti rumah), Masjid kecil ini merupakan tempat ibadah pertama di tatar Sunda dan didirikan di pesisir laut Cirebon, yaitu pada tahun 1450 M. Kata tajug ini sampai saat ini masih terpelihara dengan nama dialek Cirebon yaitu menjadi kata tajug (musholah) Pejalagrahan. Selanjutnya pada perkembangan dari tajug (musholah) peninggalan sejarah Islam di Cirebon berkembang pesat seiring penyebaran Islam, sehingga dari pihak kerajaan Islam mendirikan masjid yang berfungsi sebagai sarana ibadah, sosial, pendidikan dan politik (musyawarah).

Selanjutnya, setelah menunaikan ibadah haji ke Mekah Walangsungsang berganti nama menjadi Haji Abdullah Iman. Mulamula Syekh Nur Jati yang tinggal di Pesambangan menganjurkan agar Walangsungang pergi menunaikan ibadah haji ke Mekah. Dengan menggunakan kapal Asing dari Arab yang singgah di pelabuhan Muara Jati. Menurut Tome Pires ada sekitar 4-5 kapal besar yang singgah di Muara Jati. Kemudian

${ }^{36}$ Edi. S. Ekadjati, Penyebaran Islam di Jawa Barat, hlm. 89, lihat juga, P. S. Sulendraningrat, Sejarah Cirebon, (Cirebon: Departemen Pendidikan dan Kebudayaan Jawa Barat, 1978), hlm. 25.
Walangsungsang berangkat dengan adiknya, Rara Santang. ${ }^{37}$

Sepulang dari berhaji Walangsungsang, menguatkan misinya untuk menyebarkan ajaran Islam agar semakin masif dan meyebar luas. Walangsungsang yang setiap harinya beraktivitas di daerah pesisir untuk menangkap dan mengelolah udang kecil atau rebon, namunWalangsungsang bertempat tinggal di daerah Cirebon Girang. Seperti yang diyakini masyarakat Cirebon Girang saat ini secara geografis terletakdi perbatasan antara batas kota Cirebon, tetapi mereka yakin bahwa Makam Keramat Talun adalah tempat dulu Walangsungsang tinggal dan bertafakur untuk mencari ajaran Islam. Karena letak Cirebon Girang saat ini dekat dengan Gunung Berapi.

Fakta yang didapatkan penulis di lapangan bahwa tidak sedikit masyarakat yang berziarah dan berdiam diri di pedepokan makam Keramat Talun Mbah Kuwu Cirebon Girang, Pangeran Walangsungsang. ${ }^{38}$ Menurut Juru Bicara Keramat Talun,

\footnotetext{
${ }^{37}$ Unang Sunarjo, Meninjau Sepintas Panggung Sejarah Pemerintahan Kerajaan Cerbon 14791809, hlm. 43.

${ }^{38}$ Hasil wawancara di lapangan, dengan Juru Bicara Makam Keramat Talun dan narasumber (penziara), pada tanggal 24 Januari 2014, pukul 14.00 WIB, tempat Makam Keramat TalunCirebon Girang.
} 
bahwa dahulu Mbah Kuwu setiap harinya ngulang ngaji atau mengajarkan pelajaran tentang keislaman, selain itu Mbah Kuwu juga aktif mengajak warga untuk sholat berjamaah di masjid Jalagrahan dengan menggunakan Bareng yang dilantunkan untuk mengundang masyarakat dan menjadi tanda masuknya waktu sholat. Filosofinya Bareng merupakan wejangan yang diterima Walangsungsang dari hasil pencarian ajaran Islam, sebelumnya ia menemui Sang Hyang Naggo yang merupakan ahli agama Hindu-Budha. Kemudian setelah bertemu dengan Syekh Nur Jati, Walangsungsang menceritakan secara kronologis, oleh Syekh Nur Jati dijelaskan dari sudut ajaran Islam.

Atas penjelasan Syekh Nur Jati mengenai wejangan untuk masyarakat yang ingin menjadi orang Islam sejati, maka megamalkan azimat tersebut, atau dikenal dengan sebutan Azimat Bareng. Ada empat macam ilmu: ilmu syari'at dengan mengamalkan rukun Islam yang 5, ilmu Tarekat mengamalkan rukun iman, ilmu Hakikat dengan meluruskan tujuan ajaran Islam adalah untuk menggapai keselamatan dunia dan akhirat dan ilmu Ma'rifat yaitumengetahui adanya Allah. Menurut Harun Nasution, tasawuf bertujuan untuk memperoleh hubungan langsung dan disadari dengan Tuhan, sehingga disadari benar bahwa seseorang berada di hadirat Tuhan. Sedangkan intisari ajaran tasawuf adalah kesadaran akan adanya komunikasi dan dialog antara ruh manusia dengan Tuhan. Oleh karena itu, Walangsungsang dalam menyebarkan ajaran Islam dikemas secara sederhana dengan pendekatan kultur masyarakat Cirebon, sehingga mudah diterima.

\section{Pembuka Peradaban Islam Cirebon}

Peradaban menjadi bukti bahwa ada sebuah wujud dari aktivitas manusia dalam kemajuan suatu kebudayaan dalam persepektis sejarah. Islam menjadi keyakinan dan kepercayaan serta aturan yang mengatur hubungan antara manusia dengan Tuhannya. Manusia dengan manusia, dan muslim dengan umat Islam. $^{39}$

Awal mula Walangsungsang dalam merintis Kota Cirebon, ketika Walangsungsang selesai menempuh pendidikan Islam di Amparan Jati, beserta adiknya (Rara Santang) dan istrinya (Indang Geulis). Ketiganya tinggal di sebuah langgar (pesantren) yang diasuh oleh seorang ulama dari

${ }^{39}$ Siti Maryam, dkk, Sejarah Peradaban Islam dari Klasik Hingga Modern, (Yogyakarta: Lesfi, 2004), hlm. 10. 
Arab bernama Syekh Nur Jati. Kemudian Walangsungsang berganti nama menjadi Somadullah. ${ }^{40}$ Menurut Azra, konversi penguasa ke Islam, setelah mengucapkan dua kalimat Syahadah, mereka pun mengganti namanya sesuai dengan nama-nama Muslim.

Walangsungsang diberi tugas oleh Syekh Nur Jati untuk membuka pedukuhan yang mayoritas belum menganut agama Islam, ialah pedukuhan Tegal Alang-alang atau Lemah Wungkuk ${ }^{41}$, dalam perkembangannya pedukuhanTegal Alang-alang menjadi nagari yang besar yaitu daerah wilayahnya meliputi Caruban Larang dan Girang. Karena Walangsungsang merupakan keturunan Kerajaan maka ia tidak begitu sulit untuk merintis dan mengembangkan daerah dakwahnya.

Kondisi daerah Tegal Alangalang yang dipimpin $\mathrm{Ki}$ Gedeng Alang-alang dianggap sebagai daerah yang kelak menjadi daerah subur, karena letaknya berada di dekat pantai dan sekitar muara sungai, sehingga dari aspek transportasi akan mempermudah arus perhubungan antar kampung dan berada pusat keramaian, yaitu Pelabuhan Muara Jati. ${ }^{42}$ Dengan itu hubungan kedekatan dengan kakeknya yang bernama Ki Gedeng Tapa selaku syahbandar pelabuhan menjadi baik dalam bertukar pikiran untuk meningkatkan berkembangan pedukuhannya. Purwaka Caruban Nagari memberi catatan bahwa peristiwa tersebut terjadi yang bertepatan pada hari Ahad Kliwon 1 Suro 1358 Saka bertepatan tahun $1445 \mathrm{M}^{43}$

Upaya Walangsungsang dalam mengembangkan kampungnya dengan melestarikan hasil laut seperti udang rebon (undang kecil) sebagai bahan dasar pembuatan terasi, kelak menjadi primadona dikalangan kerajaan Sunda-Galuh dan para pedagang asing yag singgah di pelabuhan Muara Jati. sedangkan mata pencaharian Kuwu Ki Danusela dan Walangsungsang di pagi hari mereka berkebun dilahan

\footnotetext{
40 Nama Shomadullah disandang Walangsungsang harapan Syekh Nur Jati, Walangsungsang menjadi orang yang lengkap akan ilmu Allah. Lihat. Mohammad Amin, Pangeran Walangsungsang Embah Kuwu Cirebon Girang, (Cirebon: tanpa penerbit, 2008), hlm. 10.

41 Ahmad Hamam Rochani, Babad Cirebon, hlm. 94.
}

42 Besta Besuki Kertawibawa, Pangeran Cakrabuana Sang Perintis Kerajaan Cirebon, (Bandung: Kiblat, 2007), hlm. 156.

43 Ahmad Hamam Rochani,Babad Cirebon, hlm. 72. Lihat. Mohammad Amin, Pangeran Walangsungsang Embah Kuwu Cirebon Girang, Cirebon: tanpa penerbit, 2008. hlm. 11 
pertaniannya sedangkan pada malamnya mereka pembuat terasi ${ }^{44}$

Setelah sepeninggalan $\mathrm{Ki}$ Gedeng Alang-alang (Ki Danusela) selaku Kuwu pertama, Walangsungsang memegang alih kepemimpinan yang dipilih melalui hasil permusyawaratan masyarakat pedukuhan, sebagai Kuwu II. ${ }^{45}$ Sejak itu, Pedukuhan berkembang pesat dan penyebaran Islam berjalan massif, hal itu dikarenakan penguasanya yang telah menganut Islam, sehingga mempermudah Walangsungsang dalam menyebarkan Islam. Pada perkembangannya daerah Tegal Alang-Alang berkembang menjadi pedukuhan yang maju.Tak lama kemudian Walangsungsang dan adiknya Rara Santang diperintahkan untuk menunaikan ibadah haji. Setelah berhaji Rarasantang bernama Hajjah Syarifah Mudaim, sedangkan WalangsungsangCakrabuana menjadi Haji Abdullah Iman. ${ }^{46}$

\footnotetext{
${ }^{44}$ Ibid, hlm. 73.
}

45 Kepemimpinan pada saat itu tidak hanya bersifat keduniawian saja, tetapi dilandaskan dengan ajaran agama Islam, pemimpin nagari, sekaligus pemimpin umat Islam di wilayah Cirebon (Caruban), Lihat Nina Lubis, Sejarah Kota-Kota Lama di Jawa Barat, (Bandung: Alqaprin Jatinangor, 2000), hlm. 32.

46 Yoseph Iskandar, Sejarah Jawa Barat: (Yuganing Rajakawasa), Cetakan Pertama
Dengan memperhatikan gambaran peristiwa di atas maka berdirinya Nagari Caruban dengan segala kelengkapanya sebagaimana ciri dari sebuah nagari telah terwujud adanya wilayah kekuasaan dari batas Nagari Singapura, hingga wilayah Surantaka, termasuk Japura yang melingkupi Cirebon Girang, pada perkembangannya memiliki pelabuhan yang bertaraf internasional. Seiring dengna perkembangan wilayah tersebut maka dibentuk pasukan pengawal keamanan wilayah dan eksistensi agar Walangsungang diakui oleh kerajaan Padjajaran, dengan memberikan upeti kepada kerajaan. Maka kelengkapan itu menjadi fondasi Walangsungang untuk mendirikan Kerajaan yang berbasis Islam dan independensi.

\section{Pencetus Istana Pakungwati}

Kutipan Azra dalam karya A. H. Johns, perspektif Islam di Asia Tenggara ${ }^{47}$, Islam pada dasarnya adalah urban (perkotaan) dan peradaban Islam juga merupakan urban. Johns menyatakan bahwa proses Islamisasi di Asia Tenggara termasuk pelabuhan-pelabuhan di pesisir utara Jawa, bermula dari kota

(Bandung: CV. Geger Sunten, 1997), hlm. 256.

47 Azyumardi Azra, Renaisains Islam di Asia Tenggara, hlm. 33 . 
pelabuhan-pelabuhan. Di perkotaan sendiri, Islam sebagai fenomena istana kerajaan yang menjadi pusat kekuasaan atas wilayah maupun intelektual (lembaga pendidikan), sehingga kebanyakan istana-istana Kerajaan Islam berada di pusat kota, termasuk di Cirebon.

Dikisahkan

bahwa,

Walangsungsang mendirikan Masjid dan Keraton Pakungwati dengan pembiayaan dari warisan kakeknya Ki Gedeng Tapa, ${ }^{48}$ serta membuat pasukan keamanan lengkap dengan angkatan bersenjatanya. Pada saat Walangsungsang menjadi Kuwu di Caruban, Ayahnya, Raja Sunda merestui dengan mengirim Tumenggung Jagabaya membawa panji-panji kerajaan serta memberikan wilayah kekuasaan kepada Walangsungsang.

Dikisahkan pula, Perkembangan Istana Kerajaan di Cirebon yang berangkat dari Tajug Jalagrahan kemudian menjadi istana, yang disebut istana Pakungwati. ${ }^{49}$ Dalam sejarahnya, istana tersebut sebagai legitimasi Walangsungsang selaku Kuwu II Cirebon dan mendapat dukungan dari Kerajaan

48 P. S. Sulendraningrat, Purwaka Caruban Nagari, hlm. 17.

49 Besta Besuki Kertawibawa, Pangeran Cakrabuwana sang Perintis Kerajaan Cirebon, hlm. 183.
Galuh, sehingga tidak heran jika pada periode ini, Walangsungsang mempunyai kewajiban untuk meyerahkan sebagian hasil bumi yang diberikan kepada Kerajaan Galuh, sebagai upeti. Karena wilayah Walangsungsang merupakan bagian dari pusat Kerajaan Galuh.

Berawal dari sebuah pakuwon di Kebon Pesisir, ${ }^{50}$ Cakrabuana atau yang lebih dikenal dengan sebutan Mbah Kuwu Cerbon, salah satu keturunan Raja Pajajaran Prabu Siliwangi membangun Dalem Agung Pakungwati. Rasa cinta dan kasih sayangnya yang mendalam terhadap putri sulungnya mendorong Pangeran Cakrabuana untuk memberikan nama keraton yang pertama di Cirebon ini dengan nama Pakungwati. Nama Pakungwati sendiri secara etimologis berasal dari bahasa Cirebon kuno yang berarti udang betina, suatu hal yang merujuk pada kekhasan Cirebon masa lalu yang delestarikan hingga sekarang, yakni udang.

50 Keraton Kasepuhan Lokasi Kraton Kesepuhan terletak di desa (lingkungan) Lemah Wungkuk. Jika kita mengunjungi Kesepuhan dari jalan Lemah Wungkuk menuju ke selatan lurus, akan berpapasan dengan alun-alun Kraton Kesepuhan. Dari alun-alun, kraton dan kompleks kraton ada di sebelah selatannya. Tradisi menyebutkan bahwa Kraton Kesepuhan adalah kelanjutan atau perkembangan dari Kraton Pakungwati Cirebon. Lihat. Nina Lubis, Kota-Kota Lama di Jawa Barat, hlm. 44. 
Dengan ditandai berdirinya Keraton Pakungwati, berarti berdirilah sebuah kerajaan Islam pertama di tatar Sunda Pajajaran. Kerajaan Islam pertama yang didirikan oleh Walangsungsang atau Cakrabuana tersebut diberi nama Nagara Agung Pakungwati Cirebon atau dalam bahasa Cirebon disebut dengan sebutan Nagara Gheng Pakungwati Cirebon.Keraton Pakungwati berdiri pada tahun 1425 M. ${ }^{51}$ Keberadaan Keraton Kasepuhan dalam sejarahnya tidak bisa dipisahkan dari cikal bakal Ndalem Agung Pakungwati yang dibangun oleh Walangsungsang atau Cakrabuana. Tradisi menyebutkan bahwa, Kraton Kesepuhan adalah kelanjutan atau perkembangan dari Kraton Pakungwati Cirebon. Kraton Pakungwati sudah tempati oleh rajaraja Cirebon awal yang dimulai oleh Cakrabuana. Pada masa Cakrabuana, Kraton Pakungwati masih belum luas, kini tempat tersebut dijadikan tempat Ndalem Agung yang terletak dibagian timur laut kompleks Kraton Kesepuhan. $^{52}$

$$
\text { Pada }
$$

masa

${ }^{51}$ Tradisi kraton menyebutkan ukiran banteng pada tangga masuk sitiinggil keraton Kasepuhan merupakan Candra Sengkala, berdirinya kraton Pakungwati karena ukiran itu menggambarkan candra sengkala yang berbunyi Banteng Tinata Bata Kuta, 1 (kuta) 3 (bata) 4 (tinata) 7 (banteng) jadi 1347 saka atau $1425 \mathrm{M}$.

${ }^{52}$ Menurut hasil survei dan wawancara dengan abdi dalem Keraton Kasepuhan di lapangan oleh Bapak Supri, 37 tahun. pemerintahan Sunan Gunung Jati, Kraton Pakungwati mengalami pelebaran. Nama Pakungwati dilestarikan oleh raja-raja selanjudnya hingga pada masa pemerintahan Panembahan Ratoe II (GIrilaya). ${ }^{53}$ Setelah pemerintahan Panembahan Ratoe II kemudian kerajaan dibagi menjadi dua yaitu, Kraton kesepuhan dan Kraton Kanoman.

Walangsungsang membangun Keraton setelah melaksanakan ibadah Haji ke Mekah. Kiprahnya dalam mengembangkan daerah Cirebon mendapat pengawasan secara ketat dari pihak kerajaan Galuh, kemudian menyatukan beberapa daerah di sekitar Cirebon seperti negeri-negeri yang telah disebutkan dalam bab II (Surantaka, Singapura, Japura, Wanagiri) menjadikan daerahnya semakin luas dibawah pimpinan Kuwu Cirebon (Walangsungsang).

Sehingga Walangsungsang merencanakan untuk lepas dari Kekuasaan Galuh menjadikan daerah Cirebon yang independen. Berkat usaha kakeknya, Ki Gedeng Tapa yang telah memajukan Nagari Singapura, dan setelah Ki Gedeng Tapa meninggal dunia, harta warisan diberikan kepada Walangsungsang.

\footnotetext{
${ }^{53}$ Nina Lubis, Sejarah Kota-Kota Lama di Jawa Barat, hlm. 35.
} 
Walangsungsang

atau

Cakrabuana, bukan hanya sematamata untuk membentuk suatu pemerintahan areal kekuasan, namun lebih dari itu untukmegembangkan dakwah Islamiyah yang menjadi citacita saat besarnya. Kemudian akan diteruskan oleh putra dari adiknya, Nyi Mas Ratu Rarasantang, yaitu Syarief Hidayatullah. Susuhunan Jati (Syarif Hidyatullah) berkedudukan di keraton Pakungwati, sedangkan Cakrabuwana (Walangsungsang) sebagai manggalai panglima angkatan bersenjata. ${ }^{54}$

Pencetus dasar hukum sebuah Nagari Cirebon yang melandasinya adalah Islam hal itu peran dari Walangsungsang selaku ulama dan pemimpin di wilayah itu. Selain itu hukum adat masih berlaku dikarenakan hukum tersebut peninggalan Ki Gedeng Tapa sang kakek yang mendukung berdirinya sebuah Nagari dan Kuwu Cirebon I Ki Gedeng Danusela sekaligus mengingat terhadap keragaman masyarakat Cirebon hingga disebut Nagari Caruban (Cirebon). Di wilayah pesisir utara ini memiliki keunikan tersendiri dibandingkan dengan Singapura, Surantaka, Japura dan Wanagiri, yang pada

${ }^{54}$ Atja, Carita Purwaka Caruban Nagari, hlm. 37. perkembangannya termasuk dalam wilayah Cirebon.

Oleh karena itu peran Walangsungsang selain sebagai raja terdahulu Kerajaan Islam di Cirebon, juga sebagai penasehat kerajaan sekaligus pemimpin panglima bersenjata kerajaan. hal itu juga tergambar dalam pemakanai simbol berupa patung macan (singa) di depan Makam Keramat Talun Mbah Kuwu Cirebon Girang.

D. Pengaruh dari

Peran

\section{Walangsungsang}

1. Dalam Perkembangan Islam Pandangan mengenai Islam, secara filosofi istilah Islam dapat dimaknai dalam perkembangan Islam ialah membentuk negara Islam dan mengintensifkan nilai ke-Islaman dalam kehidupan bermasyarakat. Sejarah perkembangan Islam di Jawa khususnya, para penyebar Islam dengan lincah berinteraksi dengan penduduk pribumi, sehingga dengan mudah Islam mempengaruhi penduduk pribumi untuk konversi agama kepada Islam. Islamisasi melalui pendekan Tasawuf bagi para sufi dengan cara mendekatkan masyarakat serta memberikan kemudahan bagi masyarakat untuk mendekatkan diri dan memberikan cara untuk mempermudah mendekatkan diri kepada Allah swt. Disamping itu juga, mereka para sufi 
mendapatkan perhatian dari penguasa dan ditempatkan di posisi strategis dan mulyah, misalnya,dijadikan penasehat kerajaan. Sebelumnya telah dipaparkan dalam bab III, Islamisasi di Cirebon yang pada awal mula dibawa oleh para sufi profesional, seperti Syekh Nur Jati dan Syekh Hasanuddin (Syekh Qurra).

\section{Dalam Naskah Carita} Purwaka Caruban Nagari, Cariyos Walangsungsang, Tokoh Walangsungsang hidup di zaman Hindu-Budha sekaligus putra Kerajaan Sunda-Galuh didalamnya juga dikisahkan mengenai perjalanan sufistik (bagi pandangan Islam) dalam mencari agama Islam. Dengan berguru kepada ahli agama baik dari agama Hindu maupun Islam melalui Syeikh Nur Jati. Walangsungsang bagi masyarakat Cirebon, diidentifikasi sebagai "leluhure wong Cerbon". ${ }^{55}$ Mereka menghormati jasa atau peran Walangsungsang dalam menyebar luaskan ajaran Islam yang masih sederhana pada kala itu. Walangsungsang dalam meyebarkan ajaran Islam tidak meninggalkan adat kebiasaan lama (tradisi Hindu) dengan nilai Islam, sehingga budaya lama tidak hilang.

55 Dalam bahasa Cirebon, yang artinya orang yang dihormati oleh masyarakat Cirebon.
Ramainya Pelabuhan Muara Jati dan pasar Pesambangan menjadi titik tolak dari awal perkembangan Islam di wilayah pesisir Pantai Utara ini, khususnya Cirebon. Melalui hubungan dagang penyebaran Islam kemudian berkembang hingga daerah pedalaman Cirebon atau sebutan lain Cirebon Girang. Syekh Nurjati membangun pesantren di daerah pemukimannya masingmasing. Dengan berdirinya pesantren berarti ada buah pembentukan kader penyebar agama Islam. Santri-santri yang telah memahami ajaran Islam kemudian menyebarkan ajaran itu di lingkungan tempat tinggal masingmasing atau ke daerah lain atas perintah gurunya.

Islam menyebar secara bertahap melalui guru-guru agama dan institusi, sehingga menjadi agama mayoritas di Jawa. Difusi atau konversi Islam di Indonesia dapat berjalan dengan lancar karena sejumlah factor. Pertama, Islam datang di Jawa lebih awal dibanding Kristen dan para pedagang muslim menancapkan kekuasaan, ekonomi dan politiknya di tempat-tempat yang meraka singgahi. Kedua, Islam dianggap sebagai agama yang mudah untuk dilaksanakan. Ketiga, Terdapat kemiripan ajaran Islam dengan agama tradisional Jawa sufi dan magis yang ada di Islam, pada saat itu sama dengan kepercayaan 
animisme dan Hindu. Keempat, ada kemungkinan hidup bersama (keksistensi) antara agama Jawa dan Islam. Kelima, adanya kegunaan instrumental yaitu hubungan dagang, pembangunan, adalah alasan para pedagang untuk masuk Islam. Keenam, Taktik penetrasi Islam diantaranya adalah para pedagang Arab menikah dengan wanita setempat dan mengislamkan para pembantunya. Selanjutnya, para ulama datang untuk mendirikan institusi islam yaitu masjid dan pesantren.

\section{Dalam Ragam Sosial-Budaya Masyarakat Cirebon}

Dengan menganggap Agama sebagai kekuatan moral, pemberi semangat bagi perilaku manusia, berdasarkan kultur masyarakat dalam konteks ini masyarakat Cirebon. Menurut masyarakat setempat kata Caruban, artinya tempat di mana orang berbaur dan tinggal berdampingan sehingga yang dimaksudkan dengan berbaur ini memiliki spektrum yang beragam. ${ }^{56}$ Cirebon yang terletak di perbatasan

${ }^{56}$ Misalnya pada nama Caruban dan Cirebon menggambarkan warna linguistik yang menarik. Keduanya memiliki kemiripan dalam pengucapan dan menggambarkan benda yang sama. Tetapi dari makna katanya, asalnya dan artinyanya berbeda secara jelas. Antara bahasa Jawa dan Sunda. Lihat. Muhaimin AG., Islam dalam Bingkai Budaya Lokal: Potret dari Cirebon,hlm. 18. antara dunia Sunda dan dunia Jawa yang disebut sebagai kota persilangan budaya yang cukup bertahan hingga sekarang. Telah disebutkan dalam karya Denys Lombard $^{57}$, suku Sunda pada tahun 1980 bahwa meningkatnya suku Sunda ketika itu 27 juta orang, bangga akan identitas mereka dan jarang dianggap sebagai orang Jawa. Tetapi bagi sebagian masyarakat Cirebon khususnya ketika ditanya orang Cirebon tidak mengakui dari suku Jawa maupun Sunda, mereka menyebutnya asli Cirebon. Asal kata Cirebon di sini diidentifikasi sebagai budaya asli Cirebon yang terdiri dari peleburan dua budaya yaitu Jawa dan Sunda. Corak budaya dalam perspektif dialek "Cirebonan" karakter masyarakat pesisir Pantai Utara termasuk Cirebon.

Merupakan sebuah prestasi yang luar biasa sebagai kepala kampung, Walangsungang berhasil melakukan proses pergeseran masyarakat, dari masyarakat Padjajaran yang homogen (suku Sunda) ke masyarakat yang berkarakteristik heterogen, yaitu membentuk masyarakat pertanian menetap di daerah (urban). Karena dukungan kebijakan

${ }^{57}$ Denys Lombard, Nusa Jawa: Silang Budaya Batas-batas Pembaratan, (Jakarta: PT. Gramedia Pustaka Utama, 2000), buku 1, hlm. 29. 
Walangsungsang selaku Kuwu Caruban II yang mengizinkan pedagang asing singgah, bahkan menetap di daerah-daerah sekitar pantai berdampak pada kebijakan dan bertoleransi tinggi terhadap para pendatang untuk bercampur dengan penduduk pribumi masyarakat Cirebon.

\section{Intensitas kultur dari} bermacam suku dan agama yang berdampingan sehingga lambat laun yang semula penduduk pribumi menganut beragama Hindu lambat laun mengikuti agama baru (mayoritas Islam) serta didukung oleh pemimpin yang beragama Islam, sehingga proses akulturasi budaya berkembang dan mengasilkan corak keislaman yang plural. Konsep plural yang dimaksudkan di sini ialah mengakui adanya budaya dari Arab (pedagang muslim), Cina, Sunda dan Jawa sehingga mereka mampu bersosialisasi dengan massif.

Tercermin dalam beberapa tradisi yang sampai saat ini masih dilakukan masyarakat Cirebon dalam melestarikan warisan budaya terdahulu, misalnya pada tradisi ziarah (mengunjungi) atau nyepi(menginap disekitar makam) yang dianggap memberikan karamah sehingga kegiatan tersebut dikeramatkan. Menurut masyarakat,
Walangsungsang yang telah berjasa baik dalam penyebaran agama Islam (wali) juga memiliki peran penting dalam perkembangan Cirebon. Bermula dalam merintis Cirebon, sejak masih hutan belantar, kemudian menjadi sebuah pedukuhan hingga pada perkembangannya terbentuk nagari Cirebon yang mempunyai wilayah luas. ${ }^{58}$

\section{Dalam Kemajuan Keraton} Islam Cirebon

Ramainya jalur perdagangan sebagai sumber ekonomi, dan banyaknya pendatang dari negeri asing, Arab, Cina dan India. Pusatpusat perdagangan yang berada di wilayah Jawa bagian Barat, ketika pada masa Kerajaan Sunda-Galuh, ada beberapa pelabuhan yang dikendalikan oleh kerajaan, Pelabuhan Muara Jati (Cirebon), pelabuhan Dermayu (Indramayu) dan pelabuhan Banten. Dari beberapa pelabuhan di atas tidak bisa dilepaskan bahwa peranan penting perkotaan yang berada di dekat pelabuhan tersebut, seperti Pesambangan (Cirebon Larang), Lemah Wungkuk (Tegal Alangalang) dan bandar Dermayu yang

58 Hasil wawancara dengan salah satu pengunjung yang juga menyepi di sekitar makam Keramat Talun, Ibu Juminah, umur 45 tahun, hari Kamis, 19 Desember 2013, pukul 16.00 WIB. 
juga ramai dengan pedagang dari Cina muslim, Melayu Muslim, Jawa, dan Sunda yang masih beragama Hindu- Budha. ${ }^{59}$

Letak Cirebon, yang menjadi tempat pemberhentian kapal-kapal dagang bertaraf Internasional yang akan berlayar ke Sunda Kelapa mapun Malaka yang kala itu ramai karena merupakan jalur perdagangan, Saat itu Cirebon adalah kota dan kerajaan maritim. Unang Sonarjo dalam karyanya menyebutkan. setelah kokohnya pembangunan perekonomian dari perdagangan, Sunan Gunung Jati (selaku keponakan Walangsungsang) menjadi penerus dari hasil perjuangan Walangsungsang dalam merintis kota Cirebon dan Kerajaan Islam Cirebon, dengan cara penataan pemerintahan baik pusat maupun daerah.

Kota-kota tersebut di atas memiliki peranan penting dalam penyebaran Islam melalui jalur daratan. Menurut keterangan dari sumber dalam Naskah Purwaka Caruban Nagari, bahwa pada tahun abad 15 M terdapat permukiman para pedagang Arab, Cina dll. Keterangan lain menyebutkan terkait perizinan (kebijakan) Cakrabuwana

\footnotetext{
${ }^{59}$ Agus Sunyoto, Suluk Abdul Jalil Perjalanan Ruhani Syeikh Siti Jenar, sebuah Novel Sejarah jilid 1, (Yogyakarta: Lkis, 2003), hlm. 39.
}

(Walangsungsang) kepada Syarif Abdurachman

(Pangeran Panjunan) ${ }^{60}$ yang diberi wilayah di daerah padukuhan Panjunan dan disahkan pada tahun $1464 \mathrm{M}^{61}$

Jadi pengaruh penguasa dibawah pimpinan Walangsungang sebagai penganut Islam memberikan ruang terbuka bagi pendatang yang berkeinginan untuk berniaga maupun ikut serta menyebarkan Islam di Cirebon agar semakin intensif dalam menjalankan cita-cita Walangsungsangyang berkeinginan untuk mendirikan negara Cirebon, agar berdiri kerajaan yang berbasis Islam. Kebijakan Walangsungsang untuk memberikan sebagian wilayahnya kepada para pendatang yang ingin bermukim di Cirebon merupakan salah satu dari kebijakan politik, karena hanya daerah-daerah kebuyutanlah yang diberi hak otonom untuk para pendeta atau

60 Syarif Abdurachman (Pangeran Panjunan) merupakan pendatang dari Bagdag yang berniat untuk menimba ilmu kepada Syeikh Nur Jati di Giri Amparan Jati (Gunung Jati). Lihat P.S Sulendraningrat, Sejarah Cirebon, hlm.

61 Pedukuhan Panjunan nama sebuah daerah yang awalnya hutan belantara, menjadi padukuhan yang memiliki kerajinan tangan penduduk sekitar dalam membuat alat-alat rumah tangga dari tanah liat atau gerabah. Lihat. Jurnal Sejarah dan Kebudayaan Islam, Thaqofiyyat, Riswinarno dan Laeli Wijaya, "Interaksi Budaya Pada Masjid Panjunan Cirebon Jawa Barat",Thaqafiyyat, Vol. 10, No. 2 Juli-Desember 2009, hlm. 239-240. 
pemuka agama sekaligus dilandasai faktor ekonomi. Faktor tersebut menjadikan adanya rasa persaudaraan antarpedagang Muslim, yang menyebabkan Cirebon berkembang dan tumbuh menjadi kota pelabuhan dan ibukota kerajaan Islam di Jawa Barat. $^{62}$

Kerajaan Sunda-Galuh yang beribukota di Galuh, sedangkan kerajaan Padjajaran sendiri beribukota di Pakuan Padjajaran, tepatnya di Ciamis, Bogor Jawa Barat. Dulu, kewajiban utama bagi daerah kuasa Sunda-Galuh salah satunya Nagari Caruban (Cirebon) kala itu, memberikan upeti berupa hasil bumi dan kekayaan lainnya. Semisal di Cirebon, pada masa Kuwu I Caruban yang dipimpin Ki Danusela (kerabat Ki Danuwarsih) yang menekuni pencahariannya di bidang nelayan. Ki Danusela setiap hari bekerja mencari udang kecil (rebon) di pesisir Pantai Utara Pelabuhan Muara Jati. Dari hasil tangkapanya kemudian diolah menjadikan sebuah produk yang dikemudian hari menjadi primadona, yaitu terasi. Selanjutnya dikembangkan oleh Walangsungsang yang kala itu sebagai pangraksabumi pakuwuan Cirebon.

62 Besta Basuki Kertawiba, Pangeran Cakrabuana Sang Perintis Kerajaan Cirebon, (Cirebon: Kiblat Buku Utama, 2007), hlm. 173174.
Terasi menjadi khas di kalangan penduduk Cirebon maupun Jawa Barat pada umumnya. Kerajaan Padjajaran menjadikan terasi sebagai primadona di kalangan kerajaan tersebut. Sehingga di masa pemerintahan

Walangsungsangsebagai Kuwu II Nagari Caruban (Cirebon) terasi diproduksi sebagai produk jual beli di pelabuhan Muara Jati yang ramai disinggahi kapal-kapal asing dari berbagai Negeri Arab, Cina, India, dll. ${ }^{63}$

Ketika jalur perdagangan ramai yang datang dari negera-negara asing yang sebagian besar telah memiliki agama Islam, sehingga tidak mempersulit para pedagang untuk singgah di pelabuhan Muara jati dikarenakan penguasa wilayahnya adalah Walangsungsang yang telah memeluk Islam. Kemudian, Walangsungsang memanfaatkan peluang ini untuk mengembangkan daerahnya dalam sektor perdagangan, dan hal ini merupakan strategi atau metode Walangsungsang dalam meningkatkan sumber ekonomi bagi penduduk asli (Cirebon).

Pada perkembangannya pengislaman masyarakat Cirebon

63 Besta Basuki Kertawibawa, Pangeran Cakrabuwana Sang Perintis Kerajaan Cirebon, (Bandung: Kiblat, 2007), hlm. 112. 
oleh Walangsungsang berlangsung mulus. Hal itu dapat dibuktikan dengan meningkatnya masyarakat yang menganut Islam dibawah kepemimpinan Walangsungsang. Menurut Besta Basuki yang mengutip dari Yuseph Iskandar, sejak dibukanya pedukuhan Cirebon pesisir setelah dua tahun (1447 M), tercatat peningkatan angka jumlah penduduk baik dari penduduk asli (suku Sunda, Jawa) maupun penduduk pendatang. ${ }^{64}$

Sebagai sosok kelahiran tanah Sunda 1445 M, Walangsungsang meninggalkan pengaruh terhadap kejayaan kesultanan Islam Cirebon yang mengalami puncak kejayaannya pada masa kepemimpinan Sunan Gunung Jati. Termasuk hasil dari sejarah panjang bagi masyarakat Islam di Cirebon, ialah Kraton Kasepuhan, Kanoman dan Kacirbonan yang merupakan hasil perkembangan dari istana Pakungwati (Ndalem Agung Pakungwati). ${ }^{65}$

64 Besta Basuki Kertawibawa, PangeranCakrabuwana Sang Perintis Kerajaan Cirebon, (Bandung: Kiblat, 2007), hlm. 169, Lihat Juga Yuseph Iskandar, Sejarah Jawa Barat (Yuganing Rajakawasa), (Bandung: Geger Sunten, 1997), hlm. 256-257.

${ }^{65}$ Kini tinggal puing bekas istana Pakungwati yang berada di dalam lingkungan Keraton Kasepuhan.
Sejak dahulu istana Pakungwati merupakan tempat tinggal Walangsungsang dan sekaligus tempat peyebaran dan tempat mengajarkan ajaran Islam kepada masyarakat sekitar Cirebon Larang (Pesambangan). Kemudian atas kebijakan Kerajaan PadjajaranWalangsungsang diberi hak otonomi daerah agar istana Pakungwati menjadi sebuah pusat kerajaan yang dalam pengawasan kerajaan Padjajaran (Kerajaan Galuh). Sehingga tidak heran jika Walangsungsang atau Cakrabuwa sebagai Kuwu II yang memiliki wilayah luas yang melingkupi kawasan Cirebon Larang dan Cirebon Girang, namun harus memberikan upeti kepada kerajaan Galuh, berupa hasil bumi.

Pada perkembangannya, bahwa Sunan Gunung Jati atau Syarif Hidayatullah (keponakan Walangsungsang dari Rara Santang) mendarat di Pelabuhan Muara Jati dengan maksud untuk menyebarkan Islam di tanah kelahiran ibunya (Rara Santang) yaitu di wilayah Jawa Dwipa. ${ }^{66}$ Selanjutnya dalam sumber tradisional menerangkan bahwa, bertemunya Walangsungsang dengan keponakannya Syarif Hidayatullah (yang selanjutnya disebut Sunan

66 P. S. Sulendraningrat, Carita Purwaka Caruban Nagari, hlm. 30. 
Gunung Jati) menjadi awal dimulainya negeri Cirebon yang semula dibawah kekuasaan kerajaan Galuh menjadi sebuah kerajaan yang independen, dan tidak lagi memberikan upeti. Sehingga dalam sumber sejarah disebutkan bahwa sejak Negeri Cirebon melepaskan diri dari kekuasaan kerajaan Galuh, Walangsungsang menetapkan Sunan Gunung Jati sebagai Penetep Panutagama Sinuhun (raja pertama) dengan kerajaan yang berlandaskan ajaran Islam sebagai nilai-nilai kehidupan bagi masyarakat Islam, sejak itu pula Islam mulai berkembang pesat dan memiliki jangkauan wilayah yang luas. Walangsungsang yang telah memberikan atau mengalihkan kekuasaannya kepada Sunan Gunung Jati, sedangkan peranan Walangsungsang kini sebagai penasehat kebijakan raja (kerajaan).

\section{E. Penutup}

Dapat disimpulkan bahwa Walangsungsang sejak kecil dididik oleh Subang Larang dengan kultur Islam. Peran dan Pengaruh Walangsungsang dalam Islamisasi di Cirebon, diantaranya adalah sebagai penyebar Agama Islam, pembuka peradaban Islam, pencetus Istana Pakungwati sebagai simbol kekuasaan Islam di Cirebon. Peran Walangsungsang memberikan pengaruh dalam kegemilangan Kerajaan Islam yang dipimpin Syarif Hidayatullah (Sunan Gunung Jati) Tumenggung yang bergelar Susuhunan tahun 1479 M. Jadikurang lebih dalam kurun waktu tiga puluh empat tahun jaraknya sejak dipimpin oleh Kuwu hingga Susuhunan. Artinya perjuangan Walangsungsang dalam menyebarkan Islam, pembuka peradaban Islam Cirebon, dan pencetus Istana Pakungwati yang kemudian menjadi sebuah keraton berbasis Islam.Walangsungsang (Cakrabuwana) sebagai uwak dan penasehat kerajaan berharap setelah Kerajaan berdiri menjadi daerah teritorial dan penetapan sistem pemerintahan bebasis Islam serta perekonomian menjadi semakin massif dan berkembang.

Signifikansi tulisan ini untuk menunjukkan adanya pembuktian atau penegasan akademik bahwa Walangsungsang yang lebih populer dengan nama Cakrabuwana itu bukan sekedar tokoh legenda, mitos, atau semacamnya, melainkan nyata bagian dari tokoh historis dan fakta sosial melalui rekonstruksi historis peradaban Islam Nusantara, terutama di Cirebon pada tahun 1445-1479 M. Secara strategis, tulisan ini diharapkan mampu menjadi kelengkapan khazanah sejarah Islam Indonesia dalam konteks 
rekonstruksi sejarah Islam Nusantara dan kehidupan keagamaan masyarakat, terutama di Cirebon.

\section{Daftar Pustaka}

\section{Naskah}

Kelana, Adi Jaya, Cariyos Walangsungsang, Ter. Rafan Hasyim. S, dkk.

\section{Buku}

Adeng, dkk., Kota Dagang Cirebon Sebagai Bandar Jalur Sutra, Jakarta: Departemen Pendidikan Kebudayaan RI, 1998.

Amin, Muhammad, Pangeran Walangsungsang (Embah Kuwu Sangkan Cirebon Girang) Penyebar Agama Islam di Tanah Cirebon, Cirebon: tanpa penerbit, 2008.

Anderson, Benedict R. O’ G, Mitologi dan Toleransi Orang Jawa, Yogyakarta: JEJAK, 2008.

Atja, Carita Purwaka Caruban Nagari, Bandung: Proyek Pengembangan Permuseuman, 1986.

Azra, Azyumardi, Islam In Tthe Indonesian World An Account of Institutional Formation, Bandung: Pustaka Mizan, 2006.

Azra, Azyumardi, Jaringan Ulama Timur Tengah dan Kepualauan
Nusantara abad XVII \& XVIII, Jakarta: Kencana, 2007.

Azra, Azyumardi, Perspektif Islam di Asia Tenggara, Jakarta: Obor Indonesia, 1989.

Azra, Azyumardi, Renaisans Islam Asia Tenggara: Sejarah Wacana dan Kekuasaan, Bandung: Rosda, 1999.

Ekadjati, Edi. S, Penyebaran Islam di Jawa Barat, Bandung: Dinas Pariwisata dan Kebudayaan Jawa Barat, 1975.

Gottschalk, Louis, Mengerti Sejarah, Terj. Nugroho Notosusanto, Jakarta: UI Pres, 1985.

Hadi, Sutrisno, Metodologi Research, Yogyakarta: Andi Offiset, 1990.

Hasyim, Rafan S. dkk, Cariyos Walangsungsang, BandungJawa Barat: DISBUDPAR, Tanpa tahun terbit.

Haviland, A Wiliam, Antropologi, Jakarta: Erlangga, 1993.

Huda, Nor, Islam Nusantara, Yogyakarta: Ar-Ruz Media, 2007.

Iskandar, Yoseph, Sejarah Jawa Barat: (Yuganing Rajakawasa), Cetakan Pertama, Bandung: CV. Geger Sunten, 1997.

K. Syafei, Suwarno, Kosoh S, Sejarah Daerah Jawa Barat, Jakarta: 
Departemen Pendidikan dan Kebudayaan, 1994.

Karim, Abdul, Sejarah Pemikiran dan Peradaban Islam, Yogyakarta: Bagaskara, 2011.

Kartodirjo, Satono, Pendekatan Ilmu Sosial dalam Metodologi Sejarah, Jakarta: Gramedia, 1992.

Kertawibawa, Besta Besuki, Pangeran Cakrabuana Sang Perintis Kerajaan Cirebon, Bandung: Kiblat, 2007.

Kuntowijoyo, Pengantar Ilmu Sejarah, Yogyakarta: Bentang, 1995.

Lubis, Nina, Sejarah Kota-Kota Lama di Jawa Barat, Bandung: Alqaprin Jatinangor, 2000.

Maryam, Siti, dkk, Sejarah Peradaban Islam dari Klasik Hingga Modern,Yogyakarta: Lesfi, 2004.

Nawawi, Hadiri, Metode Penelitian Bidang Sosial, Yogyakarta: Gajah Mada University Prees, 1993.

Raffles, Thomas Stamford, The History of Java, Yogyakarta: Narasi, 2008.

Rochani, Ahmad Hamam, Babad Cirebon, Cirebon: Dinas Kebudayaan dan Pariwisata Kota Cirebon, 2008.
Sewing, Ahmad M, Islamisasi Kerajaan Goa (Abad XVI-XVIII), Jakarta: Yayasan Obor Indonesia, 2005.

Sjamsuddin, Helius, Metodologi Sejarah, Yogyakarta: Ombak, 2007.

Sulendraningrat, P. S, Sejarah Cirebon, Cirebon: Departemen Pendidikan dan Kebudayaan Jawa Barat, 1978.

Sulendraningrat, P. S, Purwaka Tjaruban Nagari, Djakarta: Bhratara,1972.

Sunarjo, Unang, Meninjau Sepintas Panggung Sejarah

Pemerintahan Kerajaan

Cirebon 1479-1809, Bandung: Tarsito, 1983.

Surakhmad, Winarno, Penelitian Ilmiah, Bandung: Tarsito, 1994.

Sunyoto, Agus, Suluk Syekh Abdul Jalil perjalanan Ruhani Syeikh Siti Jenar Tinjauan Sejarah Tradisional di Cirebon, buku satu,Yogyakarta: Lkis, 2012.

Syam, Nur, Islam Pesisir, Yogyakarta: Lkis, 2005.

Zoetmulder, P.J. Kamus Jawa KunoIndonesia, terj. S.O. Robson, Jakarta: PT.Gramedia Pustaka, 2007. 
Makalah, Jurnal

"Cirebon sebagai Bandar Jalur Sutra" (Kumpulan Makalah Diskusi Ilmiah), Jakarta: Dinas Pendidikan dan Kebudayaan Cirebon, 1997.

Riswinarno dan Laeli Wijaya, Interaksi Budaya Pada Masjid Panjunan Cirebon Jawa Barat, Thaqofiyyat, Vol. 10, No. 2 JuliDesember 2009.

\section{Skripsi, Tesis}

Darkum, Peranan Walangsungsang dalam Merintis Kesultanan Cirebon 1479-1529 M., Semarang: Universitas Nagari
Semarang, Fakultas Ilmu Sosial Jurusan Pendidikan Sejarah, 2007.

Muhaimin, AG., Islam dalam Bingkai Budaya Lokal: Potret dari Cirebon, Jakarta: Logos, Yayasan Adikarya, dan The Ford Foundation, 2002.

Royani, Ahmad., Kerajaan Islam Cirebon masa Susuhan Syarif Hidayatullah tahun 1479-1588 $M$, Yogyakarta: Fakultas Adab Jurusan Sejarah Peradaban Islam, 2000. 